\title{
Essentialism and anti-essentialism in "The Evening and the Morning and the Night", by Octavia Butler
}

This paper presents partial results of the project entitled $O$ utopismo literário de autoria feminina em língua inglesa: diálogos férteis com a crítica feminista, a antropologia e a biologia evolutiva (Ufal / IOC, FIOCRUZ / UERJ), sponsored by the CNPq.

\section{ILDNEY CAVALCANTI}

$\mathrm{PhD}$, pesquisadora e professora do Programa de Pós-graduação em Letras e Linguistica, Faculdade de Letras, Ufal.

Abstract: Despite the fact that feminist literary criticism can boast a much longer history than that of the feminist critique of science, both can be grouped under the umbrella term "gender studies" and are able to jointly illuminate certain issues related to questions of gender and science. In the present work, we propose to carry out a reading of Octavia Butler's "The evening and the morning and the night" which departs from these feminist battlegrounds, dealing with the opposite yet complementary viewpoints from the biological and social sciences. Special attention is given to the concept of essentialism, as Butler's work, in all its complexity, can both confirm and disrupt its precepts.

\section{LUCIA DE LA ROCQUE}

$\mathrm{PhD}$, pesquisadora e professora do Instituto Oswaldo Cruz, FIOCRUZ, e do Instituto de Letras, UERJ.

Resumo:Apesar d a crítica literária feminista possuir uma história bem mais longa que a da crítica feminista da ciência, ambas podem ser agrupadas sob o termo guarda-chuva "estudos de gênero", sendo capazes de, juntamente, iluminar certos assuntos relacionados às questőes de gênero e ciência. Neste trabalho, é nosso propósito realizar uma leitura do conto "The evening and the morning and the night" a partir dessas arenas teóricas feministas, lidando com os pontos de vista ao mesmo tempo opostos e complementares das ciências biológicas e sociais. Atenção especial é dada ao conceito de essencialismo, que o conto em questão ao mesmo tempo confirma e estilhaça. 

The word is made flesh in mortal naturecultures.

Donna Haraway, The Companion Species Manifesto.

\section{Introduction}

Virginia Woolf's groundbreaking and still inspiring tract $A$ Room of One's Own (1929) opens up the path to a kind of reading approach which observes issues related to gender representation and to the production and circulation of women-authored texts. Almost eighty years have passed since the publication of Woolf's analysis and feminist literary criticism, or gender studies (as the area has been named recently), still offers instigating ways of looking at literary texts. The feminist critique of science, however, has a much shorter history. For over three decades now, "feminists have successfully used the lens of gender to critique the extent to which androcentric bias has distorted the theory and practice of science" (ROSSER, 1991, p. 143). ${ }^{1}$ With the present reflection, we continue somehow carrying out the programs of both of these extensive feminist tasks while, at the same time, sharing our experiences in the construction of an interdisciplinary reading practice.

This study presents partial results of our current research on the convergences between utopian and dystopian women-authored fictions, gender studies and the discourses of evolutionary biology and the social sciences. Since the publication of Mary Shelley's Frankenstein (1818), utopian and dystopian speculative fictions by women have dealt with the apparently opposed explanations for human behaviour which arise from both the biological and the social sciences. These explanations involve questions relating to gender roles, like maternity, motherhood, division of domestic chores, among several types of gender-bound activities (DE LA ROCQUE \& TEIXEIRA, 2001; DE LA ROCQUE, 2002, 2004, 2006, 2006a). Our research interests (in feminist criticism as well
${ }^{1}$ In her article, Rosser is interested in the extension of such critique leading to ecofeminist theories. 
${ }^{2}$ New York / London:

Four Walls Eight

Windows, 1995. This is

the edition used in this study. Quotations will be followed by page numbers.

${ }^{3}$ Recent discussions on the genre include Baccolini \& Moylan eds. (2003); Jameson (2005); Mohr (2005). In Brazil, some of the readings produced by members of the GT A Mulher na Literatura also focus on such convergences: see, for instance, Cavalcanti on dystopias (2000; 2003; 2004; 2005; 2006a; 2006b), Funck on utopias (1993; 1998), and De La Rocque on feminist science fiction (2001, 2002, 2004, 2006, 2006a). as issues of gender and science in women-authored utopias and dystopias) have led us to carry out research which involves readings of feminist speculative fictions written from mid- $20^{\text {th }}$-century onwards in order to observe the famous and polemic debate between the biological sciences, specifically evolutionary biology, and the social sciences, with special focus on anthropology, in the light of the relative importance of nature and culture in the composition of such complex phenomena as gender constructions. We look at these fictions as a privileged medium for the foregrounding of issues involving gender and science and for the circulation of ideas related to critical cultural theories.

Inspired by gender theories in the convergence of feminist reading practices and the feminist critique of science, this paper offers a reading of Afro-American author Octavia Butler's short story "The evening and the morning and the night", originally published in 1987, in Omni Magazine. In the 1990s, the story circulated in the volume entitled Bloodchild and other stories. ${ }^{2}$

Moylan emphasizes that "despite the lingering presence of patriarchal privilege and power - the most effective political engagement in the sf world at this time [from the late 60 s onwards] came from feminist creative and critical work" (MOYLAN, 2000, p. 36). Actually, there has been a wave of publications in on the intersections of genre and gender in feminist sf in the English-speaking world from the 1970s. ${ }^{3}$ In agreement with his statement, we believe that science fiction by women authors deals with issues of gender and science in a variety of forms. One of these is the arena in which two conflicting perspectives are staged: the views from evolutionary biological sciences and from sociology and anthropology. Based on an interdisciplinary reading approach to literary narratives, this paper focuses on the representations of such questions in the short story mentioned above. We propose to observe and analyze the fictional representation of gender at the crossroads between the biological and cultural 
aspects, in the light of the contested debate between biological determinism (and its critique) and social constructivism, a reading route which highlights the interplay of essentialist and anti-essentialist trends in the shaping of gender constructions.

\section{Science and gender in "The evening and the morning and the night" 4}

In this part, we focus on the close dialogue between Butler's story and the biological sciences. Its main characters, Lynn Mortimer and Alan Chin, suffer from a terrible rare and progressive hereditary disease (DGD Duryea-Gode Disease), which, in their case, was inherited from both their father and mother.

The story begins by the narrator, Lynn, abruptly telling us how she had always known about the disease she carried, dormant yet in her genes but very much alive in her consciousness:

When I was fifteen and trying to show my independence by getting careless with my diet, my parents took me to a Dureya-Gode disease ward. They wanted me to see, they said, where I was headed if I wasn 't careful. In fact, it was where I was headed no matter what. It was only a matter of when: now or later. My parents were putting in their vote for later (BUTLER, 1996, p.35).

Lynn is laconic but painfully precise when she comments, right after that, the effect of this visit upon her: "I won 't describe the ward. It is enough to say that, when they brought me home, I cut my wrists. [...] Almost made it. My father dislocated his shoulder breaking down the bathroom door" Ironically, "the disease got" her father three years after this episode; it attacked him suddenly, and he killed his wife, skinning her completely, and then started tearing at his own flesh, managing to "reach his own heart before he died" (36).
${ }^{4}$ The discussion in this section draws from two previous readings of Butler's story: De La Rocque (2002) and Santos (2007). 
After her parents' appalling death, Lynn no longer yields to thoughts of taking her own life. Contrarily to that, she decides to go to college on a Dilg scholarship Dilg being "the retreat you try to send your out-of-control relatives to". She majors in Biology, and after a while becomes involved with Alan, a good student who, nevertheless, "might not get into medical school because of his double inheritance" (45), whose father had already died but whose mother, he learns after many years, had been sent to Dilg. The young couple starts to plan their marriage, and Alan asks Lynn to go visit his mother with him. At first, her memory of her visit to the DGD ward she went to with her parents being still too strong, Lynn is not keen on going, but as he tells her that the famous place is completely different from any other treatment centre, since it carries out research as well as caring for the patients, and most of the staff are controlled DGD themselves, she agrees to comply with his wish.

When they arrive at Dilg, they come upon a beautiful state, where they are met by a doctor, Beatrice, whom they are surprised to learn, is a double DGD, and well into her sixties (the ones affected by the disease usually reach no more than forty). Their surprise mounts up as they see that the house is like an art museum, with all the wonders inside made by the patients; but it certainly reaches its apex as Lynn notices that she, like Beatrice, is able to control the blind artist Naomi 's (Alan's mother, who had tore her own eyes out before coming to Dilg, but had developed into a talented sculptress since her arrival there) dangerous impulses.

It is then that they learn from Beatrice that double DGD women, like her and Lynn, thanks to a combination of the genetics of the disease itself and the sex-linked chromosomes, produce a substance that is able to control other DGDs. As Lynn apprehends this, she begins to see why she was able to restrain, even if temporarily, a girl who was undergoing a bad crisis in the ward she had visited years before, as well as understand why she has been so 
adroit at controlling the order of the house she had shared with Alan and other DGDs. Beatrice, then, insists with Lynn that she study medicine, telling her that her mission will probably be to "help start a retreat in some other part of the country", as "Others are badly needed"(61-62). The story ends as Alan and Lynn leave Dilg, the narrator speculating about her possible future, about the social responsibilities that suddenly loomed upon her, that could be seen as partly laid on her by her genetic load and that, although not particularly attractive or agreeable, she thought she was bound to consider.

Concerning the representation of biology, more specifically of genetics, and of gender, the reading of "The evening and the morning and the night" evidences that these are imbricated issues in the narrative (DE LA ROCQUE 2001; SANTOS, R. 2007). Biology is a field of study present in the work not only because Lynn is an undergraduate student in the area who visits an institution (which specializes in medical research), but also because questions relating to genetics are central to the plot for being a decisive factor for the contraction of the DureyaGode Disease. DGD is a fictional fusion of three actual rare diseases: Huntington 's disease, phenylketonuria and Lesch-Nyhan disease. ${ }^{5}$ Similarly to these illnesses, DGD is a genetic disease, its carriers having inherited it from one parent - single DGD - or both - double DGD. Ironically, the first DGDs came out as a result of their parents having undergone a specific drug treatment for the cure of cancer. Resulting from a combination of the non-fiction illnesses mentioned above, DGD main symptoms include loss of consciousness, violent behaviour and self-mutilation, as described in gruesome details in many passages of the story.

In fact, the relation of this fictional disease that Butler has made up to real life maladies goes far beyond the sharing of symptoms. It must be kept in mind that this story first came out in 1987, when the rise in the importance of molecular genetics was in its wake. Butler, like many
${ }^{5}$ In her Afterword to the story, Butler herself reveals the sources she drew from in her search for the elements to build DGD. Cf. Butler, 1996, p. 69. 
science fiction writers, was undoubtedly endowed with a foreshadowing ability, as well as keen to make the most of the science themes circulating through the media for, according to Marcelo Leite:

Certainly, the identification of genes associated to rare genetic diseases (innate metabolism defects) had seen a dramatic rise in the 90 s, even before the completion of the spelling out of the human genome, based on the gene mapping in course (reducing to months a research time that used to take years or decades). Collins (the director of the National Human Genome Research Institute) himself, then in the University of Michigan, took part in the location and transcription of the gene which defect could lead to cystic fibrosis, a disease in which an excess of fluid production can be lethal; despite of this discovery, which took place in 1989 , until nowadays, the knowledge of the location of the gene in the genome and of its sequence has not originated either a treatment or a cure. (LEITE, 2006, p. 35-36)

The so far unfulfilled hope that finding out more about genes would eradicate the related diseases is reflected in this statement of Lynn's, when trying to convince her boyfriend Alan to remain at Dilg after they graduate: "Genetic engineering will probably give us the final answers, but for God's sake, this is something we can do now!" (BUTLER, 1996, p. 64). Despite Lynn's apparent trust in the future results to be drawn from the field of gene therapy, it is clear, however, that the cure for the terrible imaginary infirmity is still lost in the research horizon, although the gene responsible for the malady is known to be embedded in the region of the sex chromosomes. In fact, this location is directly implied in the imbrication of scientific and gender-related issues in Butler's futuristic dystopia, which is made evident when Beatrice, the scientist who develops research with DGD patients in Dilg, explains to the protagonists that the genetic 
modification suffered by the DGD carriers affects women and men differently. Again, this sex effect difference is not something Butler just made up, since in diseases like hemophilia this pattern is also found:

The genes responsible for producing Factors VIII and IX, the mutant genes in hemophilia, are situated on the X chromosome. This makes hemophilia a sex-linked genetic disorder

Carriers (only women) have one normal X chromosome and one abnormal X chromosome. The normal $\mathrm{X}$ chromosome produces a certain amount of Factor VIII or IX clotting factor. This protects carriers from the most severe form of hemophilia in which the level of clotting factor is less than 1\%. (http://www.hemophilia.ca/en/ 2.5.1.php)

If, in hemophilia, women are mostly carriers and men directly affected by the disease, it is not hard to see for instance that, in a family where there are affected men, who got it from their carrier mother, there may be more than a little social pressure enveloping the atmosphere between its members. This sex difference in the disease pattern, and its reflection on the social and gender sphere, is also very much felt at the end of "The evening and the morning and the night", when the protagonist' s important, almost mandatory future role in running an establishment like Dilg is played out against her medical student boyfriend's relative uselessness in the disease control. Thus, it can be said that, in Butler's work, reflecting what may happen in reality, the difference effected in the biology of human beings (in their genetic load) has extensions in their social behaviour. For gender-informed readers, this plot detail inevitably leads to questions of essentialism and anti-essentialism in feminist thought and theory, which will be addressed in the next section. 


\section{The essentialism/anti-essentialism debate}

Judith Butler contends that when Simone de Beauvoir stated, in the late 1940 's, that "one is not born a woman, but rather becomes one"6, the French philosopher herself did not envisage the "seemingly radical consequences" implied by her theory (BUTLER, 1990, p. 12). Indeed, the famous statement opened up the controversy between essentialist versus anti-essentialist views of woman that was to structure feminist thought to the present time. In general terms, "[e]ssentialism is classically defined as a belief in true essence - that which is most irreducible, unchanging, and therefore constitutive of a given person or thing". Essentialist views have informed a variety of discursive practices, reactionary or

${ }^{6}$ In The second sex (1953). progressive depending on reading positions, ranging from the scientific discourses of biologic determinism concerning sexual differences to second wave feminist thought, being "located in appeals to a pure or original femininity, a female essence, outside the boundaries of the social and thereby untainted (though perhaps repressed) by a patriarchal order" (FUSS, 1990, p. 2).

The elaboration in feminist thought and theory of the 1980 's, which resulted in the recognition of the existence of historical, class-related, gender oriented, ageeffected differences among women, and thus, that they were not to be considered as a monolithic bloc, led to the articulation of an anti-essentialist position, based on social constructionism. Such trend, according to Fuss,

insists that essence is itself a historical construction. Constructionists take the refusal of essence as the inaugural moment of their own projects and proceed to demonstrate the way previously assumed self-evident kinds (like 'man' or 'woman') are in fact the effects of complicated discursive practices. (2)

While essentialists tend to view the subject as a natural, biological entity on which social forces act, anti-essentialists, following de Beauvoir, understand 
that the very nature that defines the subject is in itself a social construct.

Despite the predominance of social constructionist positions in the feminist discourse produced in the 1980 's, 1990 's and early $21^{\text {st }}$ century, "one can also hear echoing from the corners of the debates on essentialism renewed interest in its possibilities and potential usages, sounds which articulate themselves most often in the form of calls to 'risk' or to 'dare' essentialism" (xii).

In our reading, we argue that, in "The evening and the morning and the night", Octavia Butler 'dares' to (re)turn to essentialism in the shape of a very special type of biological determinism. The analysis that follows looks at Butler's dystopia as a cultural expression of the 'risk' taken and suggests that the author deploys essentialism in an elaborate, strategic way in her narrative as a means to provoke a rupture with the dichotomous perspective on the essentialism/anti-essentialism issue. In so doing so, she reintroduces the ontology of the body in feminist discourse.

\section{The word is made flesh...}

The "word is made flesh" in Butler's story in the sense that the representation of the sexed body is constructed in such detail so as to provide the somehow plausible explanation that chemicals may affect humans on the genetic level; also to the extent that, depending on different female or male chromosomal configurations (XX for females and XY for males) such effects result in distinct consequences for men and women, as evidenced in the following passage, in which we quote Beatrice's narration of the sexually-determined differences in the DGD manifestation:

"It's a pheromone. A scent. And it's sex-linked. Men who inherit the disease from their fathers have no trace of the scent. They also tend to have an easier time with the disease. But they' re useless to use as staff here [at Dilg]. Men who inherit from their mothers have as much of the scent as men get. They 
${ }^{7}$ An excellent critique which exposes the androcentric bias in the scientific discourse of biological determinism is found in Gould, 2003; Keller, 1985 ; Schiebinger, 1999).

${ }^{8}$ Cf. De La Rocque 2002 for an analysis of this passage. can be useful here because the DGDs can at least be made to notice them. The same for women who inherit from their mothers but not their fathers. It's only when two irresponsible DGDs get together and produce girl children like me or Lynn that you get someone who can really do some good in a place like this." She looked at me [Lynn]. "We are very rare commodities, you and I. When you finish school you 'll have a very well-paying job waiting for you." (BUTLER, 1996, p. 61)

This excerpt raises evidence that the genetically inherited and sexually differentiated impact on the carriers of the disease results positive for the double DGD women, like Lynn, who become "very rare commodities" in the medical scene. This detail provides a renewed take on essentialism: while essentialist discourse (specially the one characterized by biological determinism) has been one of the sites of gender oppression for women and other cultural Others ${ }^{7}$, Butler's strategic deployment of essentialism acts on a contrary movement and favours women. This, in turn, provokes an instance of gender-role reversal. This is strikingly clear in the passage in which Lynn reiterates Beatrice's invitation for them to work at Dilg by arguing that this is something they can do as an attempt to help DGD patients and themselves. Alan's irritated reply is: "It's something you can do. Play queen bee in a retreat full of workers. I've never had any ambition to be a drone" $\left(64\right.$, italics in the original). ${ }^{8}$

Two further aspects are worthy of mention at this point. First, we will remember that DGD is the side effect of chemical cancer treatment. DGD carriers are, thus, directly or indirectly, genetically-modified bodies. After all, Hedeonco, "the magic bullet, the cure for a large percentage of the world' s cancer and a number of serious viral diseases - and the cause of the Dureya-Gode disease (DGD)" (46) is, to the biologically informed readers, clearly a germ cell mutagen, and 
Germ cell mutagens produce heritable gene mutations, and heritable structural and numerical chromosome aberrations in germ cells. The consequences of germ cell mutations in subsequent generations include genetically determined phenotypic alterations without signs of illness, or reduction in fertility, or embryonic or perinatal death, more or less severe congenital malformations, or genetic diseases with various degrees of health impairment. The term 'germ cell mutagenicity' refers specifically to mutagenicity in male and female germ cells and is distinguished from mutagenicity in somatic cells which can initiate cancer (Adler et al, in http://www.swan.ac.uk/cget/ejgt/mak.htm.

In "The evening and the morning and the night" Heldeonco is, ironically, a germ cell mutagen which, at the same time, had been successfully employed against cancer, often initiated by somatic cell mutagens... Once more, Butler has done her biological background homework very efficiently. If we have not yet heard of any disease like DGD resulting from a cancer drug treatment, it is easy to recall the name of Thalidomide, which, although not mutagenic (SANTOS, 2007, p. 154) "first synthesized in 1953, was widely prescribed for morning sickness of pregnant women from 1957 to 1961 , when it was found to be seriously teratogenic, having caused serious birth defects"(LIMA, FRAGA \& BARREIRO, 2001, p.1). Besides, it is no surprise in medical circles that there is often an association between the radiotherapy employed for cancer treatment and the emergence of a secondary tumour (DJUZENOVA et al, 2006; KAPRELYAN et al, 2005).

Nevertheless, for our present purpose, we must insist that DGD is not only the result of a genetic modification in a germ cell, and therefore inheritable but, and that is where we come to our second point, its etiology is, like hemophilia, sex-linked. If this were not enough, there is still the fact that, depending on the victims' family 
history, these effects are characterized by further difference within the same sex: only double DGD female carriers like Beatrice and Lynn have the pheromone which is decisive in the treatment of the disease. These two aspects indicate for a fundamental difference in the treatment of the issue of essentialism.

By rearticulating essentialism in such a way that bodily-related biological determinism is conveyed with a difference, that is, as a phenomenon dependent on social factors, and by valuing the female role in the human pair of male/female, Butler's short-story is actually acting on the deconstruction of the "essence" of essentialism and providing a re-reading of this category which emphasizes its characteristic as a social construct. Our analysis proposes that the author draws an interesting illustration of the possibility of manoeuvring essentialism into good feminist use.

\section{... in mortal naturecultures}

In her Afterwordto "The evening and the morning and the night", Butler affirms that she "began the story wondering how much of what we do is encouraged, discouraged, or otherwise guided by what we are genetically" (BUTLER, 1996, p. 69). In our view, by composing this thought-provoking narrative, she has accomplished a lot more than that initial idea.

While the story actually succeeds in making the author's point that "much of what we do" can be traced down to our genes, it also foregrounds the fact that the products of our genes are played out against undeniable social contexts, thus dismantling the dichotomous perspective on essentialism and anti-essentialism and reinforcing the feminist claim that sexed bodies are gendered bodies. By resorting to the convergence between genetics and the technologies that help shape our gendered bodies, Butler's story makes a feminist statement by raising our awareness concerning an understanding of our natures as shaped by the histories we are embedded in; 
or, using the neologism appropriately coined by Donna Haraway (2003) in order to stress the final impossibility of ever separating the spheres of nature and culture, of our "naturecultures". 


\section{References}

ADLER, U., KREIS, P., NEUMANN, H.G., THEIR, R., AND WILD, D. Recommendations for the categorization of germ cell mutagens. http://www.swan.ac.uk/cget/ejgt/mak.htm. Accessed in February 2008.

BACCOLINI, Raffaella; MOYLAN, Tom, eds. Dark horizons Science fiction and the dystopian imagination. New York/ London: Routledge, 2003.

DE BEAUVOIR, Simone. The second sex. Translated by H.M. Parshley. London: Jonathan Cape, 1953.

BUTLER, Judith. Bodies that matter - On the discursive limits of 'sex'. New York/London: Routledge, 1993.

BUTLER, Judith. Gender trouble - Feminism and the subversion of identity. London and New York: Routledge, 1990.

BUTLER, Octavia E. Bloodchild and other stories. New York/ London: Four Walls Eight Windows, 1995.

CAVALCANTI, Ildney. Mestras, esposas, tias e mães: as mulheres e o poder nas distopias feministas. In: CAVALCANTI, Ildney; LIMA, Ana Cecília; SCHNEIDER, Liane (Orgs.) Da mulher às mulheres: dialogando sobre literatura, gênero e identidades. Maceió: Edufal, 2006”, 230-237.

CAVALCANTI, Ildney. Oryx and Crake: restos de natureza e de cultura na distopia (quase) pós-humana de Margaret Atwood. In: CORDIVIOLA, A.; SANTOS, Derivaldo dos; CAVALCANTI, Ildney (Eds.) Fábulas da iminência: ensaios sobre literatura e utopia. Recife: PPGL/UFPE, 2006b.

CAVALCANTI, Ildney. The writing of utopia and the feminist critical dystopia: Suzy McKee Charnas 's Holdfast series. In: BACCOLINI, R.; MOYLAN, T. (Eds.) Dark horizons: science fiction and the dystopian imagination. New York / London: Routledge, 2003. 
CAVALCANTI, Ildney. Una discesa nelle distopie

contemporanee scritte da donne. Translation G.M.Basile. In:

BASILE, M.; SUVIN, D. (Eds.) Nuovissime mappe del' inferno:

distopia oggi. Roma: Monolite, 2004.

CAVALCANTI, Ildney. Utopias of/f language in contemporary feminist literary dystopias. Utopian studies 11 (2), 2000.

CAVALCANTI, Ildney. "You 've been framed": o corpo da mulher nas distopias feministas. In: BRANDÃO, I. (Ed.) Ocorpo em revista: olhares interdisciplinares. Maceió: Edufal, 2005, p 83-98.

DE LA ROCQUE, L. R.; TEIXEIRA, L. A. Frankenstein, de Mary Shelley, e Drácula, de Bram Stoker: Gênero e Ciência na Literatura. História, Ciência e Saúde-Manguinhos, Rio de Janeiro, v. 8, n. 1, p. 11-34, 2001.

DE LA ROCQUE, Lucia. Imbricações entre os temas de gênero e ciência em "The evening and the morning and the night". In GAZZOLA, A.L.; ALMEIDA, S. R. G.; DUARTE, C. L. (Eds). Gênero e representação em literaturas de língua inglesa. Belo Horizonte: UFMG Belo Horizonte, 2002, v. 4, p. 61-68.

DE LA ROCQUE, Lucia. Gênero e reprodução em questão: utopias e distopias feministas. In: ARAÚJO JORGE, T. (Eds.). Ciência e Arte: encontros e sintonias. Rio de Janeiro: Senac Rio, 2004, pp. 48-66.

DE LA ROCQUE, Lucia Entre a natureza e a cultura: gênero, ciência e poder em "Bloodchild", de Octavia Butler. In: SALGUEIRO, M. A. (Ed.) Feminismos, identidades, comparativismos: vertentes nas literaturas de língua inglesa. V. IV. Rio de Janeiro: Caetés, 2006, p. 71-82.

DE LA ROCQUE, Lucia. Marge Piercy e seus mundos de mães máquinas e ciborgues: tentativas de diluir as barreiras erguidas entre os conceitos de natureza e de cultura. In: MONTEIRO, M.C., OLIVEIRA LIMA, T.M. (Eds.) Entre o estético e o politico: a mulher nas literaturas de línguas estrangeiras. Florianópolis: Editora Mulheres, 2006, p. 315-324. 
DJUZENOVA, C.S., MÜHL, B, FEHN, M., OPPITZ ${ }^{1}$, B, MÜLLER, B. ${ }^{1}$ \& FLENTJE, M. Radiosensitivity in breast cancer assessed by the Comet and micronucleus assays.

British Journal of Cancer, 94, 1194-1203, March 2006.

FUNCK, Susana. Feminismo e utopia. Estudos Feministas 33(1), 1993, p. 33-48.

FUNCK, Susana. Feminist Literary Utopias. Florianópolis: Pósgraduação em Inglês/PPGLL, 1998.

FUSS, Diana. Essentially speaking - Feminist, nature and difference. New York and London: Routledge, 1990.

GOULD, Stephen J. A falsa medida do homem. Translated by Valter Lellis Siqueira. São Paulo: Martins Fontes, 2003.

HARAWAY, Donna. The companion species manifesto-Dogs, people, and significant otherness. Chicago: Prickly Paradigm, 2003.

JAMESON, Fredric. Archaelogies of the future - The desire called utopia and other science fictions. London: Verso, 2005.

KAPRELYAN, A, DELEVA, N. Recurrent Anaplastic Meningioma Aftersurgery And Radiation Therapy For Basal Cell Carcinoma - Case Report. Journal of IMAB - Annual Proceeding (Scientific Papers), p. 22-24, 2005, book 1.

KELLER, Evelyn Fox. Reflections on Gender and Science. New Haven: Yale University Press, 1985.

LEITE. Marcelo. Promessas do Genoma. São Paulo: Editora UNESP, 2006.

LIMA, Lídia M., FRAGA, Carlos Alberto M. e BARREIRO, Eliezer J. O renascimento de um fármaco: Talidomida. Quím. Nova, 24 (5), São Paulo, p.683-688, Sept./Oct. 2001. 
MOHR, Dunja. Worlds apart? Dualism and transgression in contemporary female dystopias. Jefferson/London: McFarland and Co., 2005.

MOYLAN, Tom. Scraps of the untainted sky-Science fiction, utopia, dystopia. Boulder/Oxford: Westview, 2000.

ROSSER, Sue V. Lessons for feminism from ecology. Women 's studies international forum 14 (3), p. 143-151, 1991.

SANTOS, Jean L.; VARANDA, Eliana A.; LIMA, Lídia M.; CHIN, Chung M. Avaliação da atividade mutagênica da talidomida pelo teste de Ames. Rev. Eletrônica de Farmácia, IV (2), p. 154-158, 2007.

SANTOS, Rosa. Gênero e biologia genética em 'The evening and the morning and the night', by Octavia Butler. Trabalho de Conclusão de Curso (Graduação em Letras) - Faculdade de Letras, Universidade Federal de Alagoas, Maceió, 2007.

SCHIEBINGER, Londa. Has Feminism Changed Science? Cambridge, Massachusetts: Harvard University Press, 1999.

OBS: For information on hemophilia the site http:// www.hemophilia.ca/en/2.5.1.php was accessed in February 2008. 